\title{
Unprecedented Restoration of a Native Oyster Metapopulation
}

David M. Schulte

College of William and Mary - Virginia Institute of Marine Science

Follow this and additional works at: https://scholarworks.wm.edu/etd

Part of the Aquaculture and Fisheries Commons, Marine Biology Commons, and the Natural Resources and Conservation Commons

\section{Recommended Citation}

Schulte, David M., "Unprecedented Restoration of a Native Oyster Metapopulation" (2012). Dissertations, Theses, and Masters Projects. Paper 1539617928.

https://dx.doi.org/doi:10.25773/v5-5npy-b939

This Thesis is brought to you for free and open access by the Theses, Dissertations, \& Master Projects at W\&M ScholarWorks. It has been accepted for inclusion in Dissertations, Theses, and Masters Projects by an authorized administrator of W\&M ScholarWorks. For more information, please contact scholarworks@wm.edu. 
Unprecedented Restoration of a Native Oyster Metapopulation

\author{
A Thesis \\ Submitted to \\ The Faculty of the School of Marine Science \\ The College of William and Mary in Virginia
}

\author{
In Partial Fulfillment \\ of the Requirements for the Degree of \\ Master of Science
}

by

David Martin Schulte

2012 


\section{APPROVAL SHEET}

This dissertation is submitted in partial fulfillment of the requirements for the degree of

Master of Science

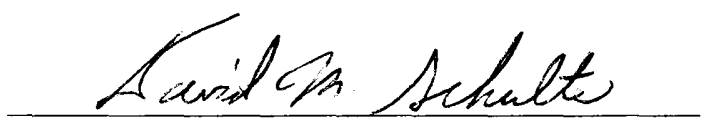

David M. Schulte

Approved by the Committee, December 2012

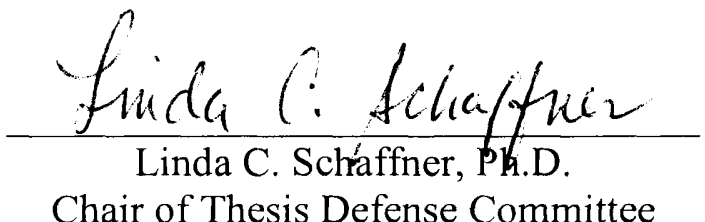

Chair of Thesis Defense Committee
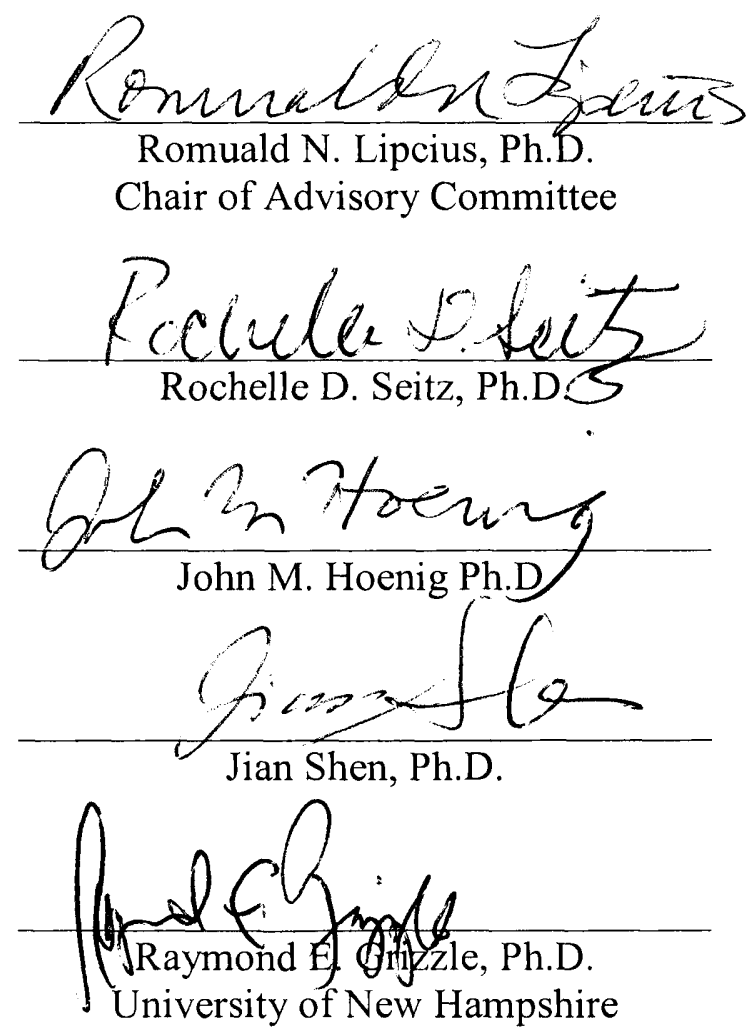
In a sense that I am unable to explicate further, the proponents of competing paradigms practice their trades in different worlds.

Thomas S. Kuhn, The Structure of Scientific Revolutions 


\section{TABLE OF CONTENTS}

Acknowledgments

\section{Unprecedented Restoration of a Native Oyster Metapopulation}

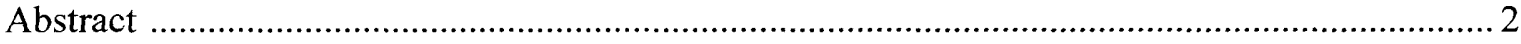

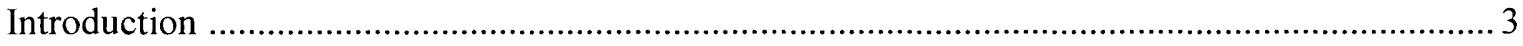

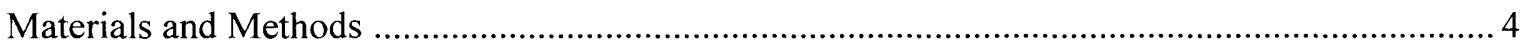

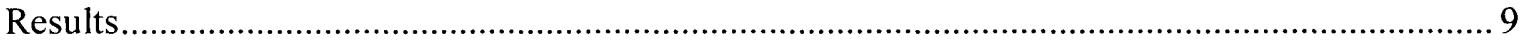

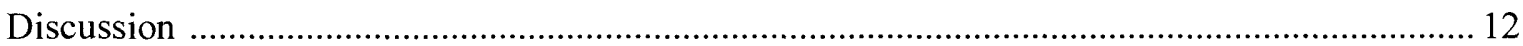

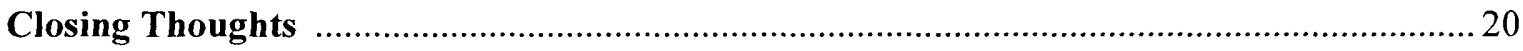

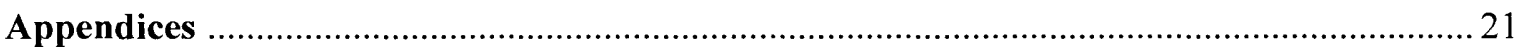

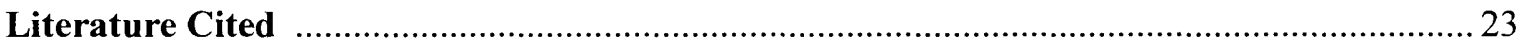

Vita 


\section{ACKNOWLEDGMENTS}

It has been an interesting and difficult journey to this point in my academic pursuits. Trying to balance academic challenges with field research and a full-time job was no easy task. Thanks to my committee, Rom Lipcius, John Hoenig, Rochelle Seitz, Jian Shen and Ray Grizzle, who were always interested in this work and helpful to me during the course of my research and study. The thesis research would have been impossible without the help of several people, Russ Burke and Danielle McCulloch in particular. Even with their help, I fell short of my academic goal, though perhaps in due time it will yet be achieved. Thanks go to the Bristow brothers, the skilled and reliable watermen who were able to take patent tong samples with the great precision this study required, where a few meters difference could change the reef type! 


\section{LIST OF FIGURES}

Figure 1: Map of the reef sites in the Great Wicomico River, Chesapeake Bay. HRR is indicated in red, LRR by stippling, and UNB by the remaining area in each of the Baylor Ground polygons.

Figure 2: Combined spat and adult oyster density as a function of the proportion of sampled HRR plots on each of the nine reefs [Least-squares regression; Spat and adult density $=165.5+992.8 \mathrm{x}$

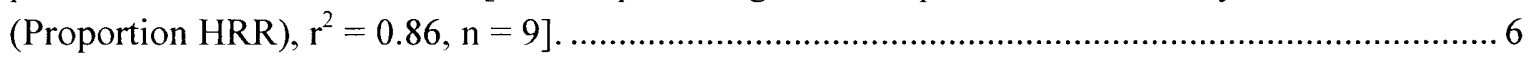

Figure 3: Size-frequency distributions of Crassostrea virginica on (a) HRR and (b) LRR treatments. 10

Figure 4: (a) Spat density as a function of adult density and (b) Accretion rate as a function of adult and spat density on each of the 85 one-square-meter plots sampled across the nine reefs. [Non-linear least-squares regression; (a) Spat density $=4.672+0.818 \times$ (Adult Density) $-0.001 \mathrm{x}$ (Adult Density) $)^{2}, r^{2}=0.54, n=85$; (b) Accretion rate $=-0.302+16.860 \times\left(1-\mathrm{e}^{-0.001 \times \text { Adult and Spat }}\right.$ Density $), r^{2}=0.86, n=85$ ]. In (b) the squares and associated crosses represent the means and SEs for each of the three treatments. 11

Figure 5: Time series of (A, B) UNB, (C, D) LRR and (E, F) HRR between 2007 and 2009..... 12

Figure 6: (a) Oyster abundance and (b) Density on each of the reef types across the nine-reef system. Values for UNB are magnified to demonstrate the similar pattern in adult and spat abundance as on the HRR and LRR patches. Abundance estimates for the system of nine reefs consisted of a total of 184.5 million oysters ( $95 \% \mathrm{Cl}: 165.0-204.0$ million), 119.2 million adults (95\% CI: $104.5-133.9$ million) of the 2005 and 2006 year classes, and 65.3 million spat (95\% CI: 59.7-77.2 million) of the newly recruited 2007 year class (Fig. 1). 16 


\section{LIST OF APPENDICES}

Page

1.1 Data Table of the winter 2007-8 survey in the Great Wicomico River, Virginia on the US

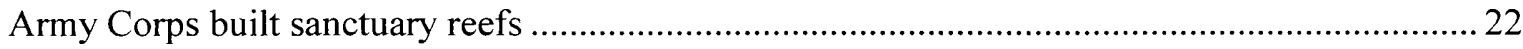




\begin{abstract}
Native oyster species were once vital ecosystem engineers whose populations have collapsed worldwide due to overfishing and habitat destruction. In 2004 we initiated a vast (35 ha) field experiment by constructing native oyster reefs of three types (highrelief, low-relief, unrestored) in nine protected sanctuaries throughout the Great Wicomico River in Virginia, USA. Upon sampling in 2007 and 2009, we found a thriving metapopulation comprising 185 million oysters of various age classes. Oyster density was fivefold greater on high-relief than low-relief reefs, explaining the failure of past attempts. Juvenile recruitment and reef accretion correlated with oyster density, facilitating reef development and population persistence. This re-established metapopulation is the largest of any native oyster worldwide, and validates ecological restoration of native oyster species.
\end{abstract}


Unprecedented Restoration of a Native Oyster Metapopulation 


\title{
Unprecedented Restoration of a Native Oyster Metapopulation
}

\begin{abstract}
Native oyster species were once vital ecosystem engineers whose populations have collapsed worldwide due to overfishing and habitat destruction. In 2004 we initiated a vast ( $35 \mathrm{ha}$ ) field experiment by constructing native oyster reefs of three types (high-relief, low-relief, unrestored) in nine protected sanctuaries throughout the Great Wicomico River in Virginia, USA. Upon sampling in 2007 and 2009, we found a thriving metapopulation comprising 185 million oysters of various age classes. Oyster density was fivefold greater on high-relief than low-relief reefs, explaining the failure of past attempts. Juvenile recruitment and reef accretion correlated with oyster density, facilitating reef development and population persistence. This re-established metapopulation is the largest of any native oyster worldwide, and validates ecological restoration of native oyster species.
\end{abstract}




\section{INTRODUCTION}

Along North American, European and Australian coastlines, native oyster populations have been devastated to less than $10 \%$ of their historical abundance through overfishing and oyster reef destruction (Rothschild et al. 1994, Jackson et al. 2001, Kirby 2004). These vital ecosystem engineers influence nutrient cycling, water filtration, habitat structure, biodiversity, and food web dynamics (Grabowski et al. 2007, Jackson et al. 2001). The widespread decline of these dominant suspension feeders was the main cause of eutrophication in estuarine ecosystems, owing to the shift from benthic to planktonic primary production and the accompanying hypoxia resulting from microbial decomposition (Jackson et al. 2001). This phenomenon remains a leading cause of ecosystem degradation in estuaries worldwide due to the largely failed efforts at oyster restoration (Lotze et al. 2006). Consequently, non-native oyster species (e.g. Pacific oyster Crassostrea gigas) were introduced in many of these ecosystems to recover lost economic and ecological benefits (Ruesink et al. 2005), despite the unnatural alteration of the world's ecosystems (Jackson et al. 2001, Lotze et al. 2006).

In Chesapeake Bay, oyster landings of the native Crassostrea virginica peaked in the 1880 s at 20-25 million bushels per year, whereas recent landings are less than 200,000 bushels (Rothschild et al. 1994). Concurrently, the natural populations were reduced to approximately $1 \%$ of historical abundance (Rothschild et al. 1994, Jackson et al. 2001, Lotze et al. 2006), despite considerable expensive attempts to restore the populations. Introductions of $C$. gigas and other species were attempted through the 1900s, but failed due to biological and environmental impediments (Mann et al. 1991). 
More recently it was concluded that revival of the native oyster is unlikely, and that introduction of non-native Asian oyster (C. ariakensis) merits consideration (US Army Corps 2009). This conclusion was based on the premise that restoration failed largely due to the inability of $C$. virginica to resist the challenge of two diseases (MSX: Haplosploridium nelsoni and Dermo: Perkinsus marinus). However, various unfished populations have overcome disease pressure by being allowed to live in protected reefs conducive to growth, survival and disease resistance (Lenihan 1999, Lenihan et al. 1999, Encomio et al. 2005). Moreover, the currently accepted strategy of attempting to restore the wild fishery and native populations in tandem allows for destructive harvest practices that devastate the structural integrity of reefs (Lenihan and Peterson 1998, 2004) and inhibit recovery. Recently, however, scattered small assemblages of $C$. virginica have been observed on natural and alternative oyster reefs protected from exploitation in Delaware Bay (Taylor and Bushek 2008), North Carolina sounds (Lenihan and Peterson 1998, Powers et al. 2009), and the Chesapeake (Lipcius and Burke 2005, Nestlerode et al. 2007), suggesting that restoration of the native $C$. virginica is feasible using novel methods.

\section{MATERIALS AND METHODS}

We report the restoration of a native $C$. virginica metapopulation in the Great Wicomico River, a sub-estuary of lower Chesapeake Bay that was selected for restoration in 2004 by the US Army Corps of Engineers (USACE). Nine reef complexes covering 35.3 ha were declared permanent sanctuaries, free from oyster fishing (Fig. 1). Pre-

restoration surveys demonstrated that there was on average less than 2 oysters $/ \mathrm{m}^{2}$ 
throughout the nine reef complexes (Fig. 2). The field experiment involved two restoration treatments [high-relief reef (HRR) and low-relief reef (LRR)] and a control treatment of unrestored bottom (UNB) spread over each of the reef complexes. In 2007 we sampled 85 one-square-meter plots, allocated randomly across the three treatments in the nine reef complexes, with patent tong and video surveys (Fig. 1). We further sampled the reefs in March 2009 to verify long-term persistence of the reefs.

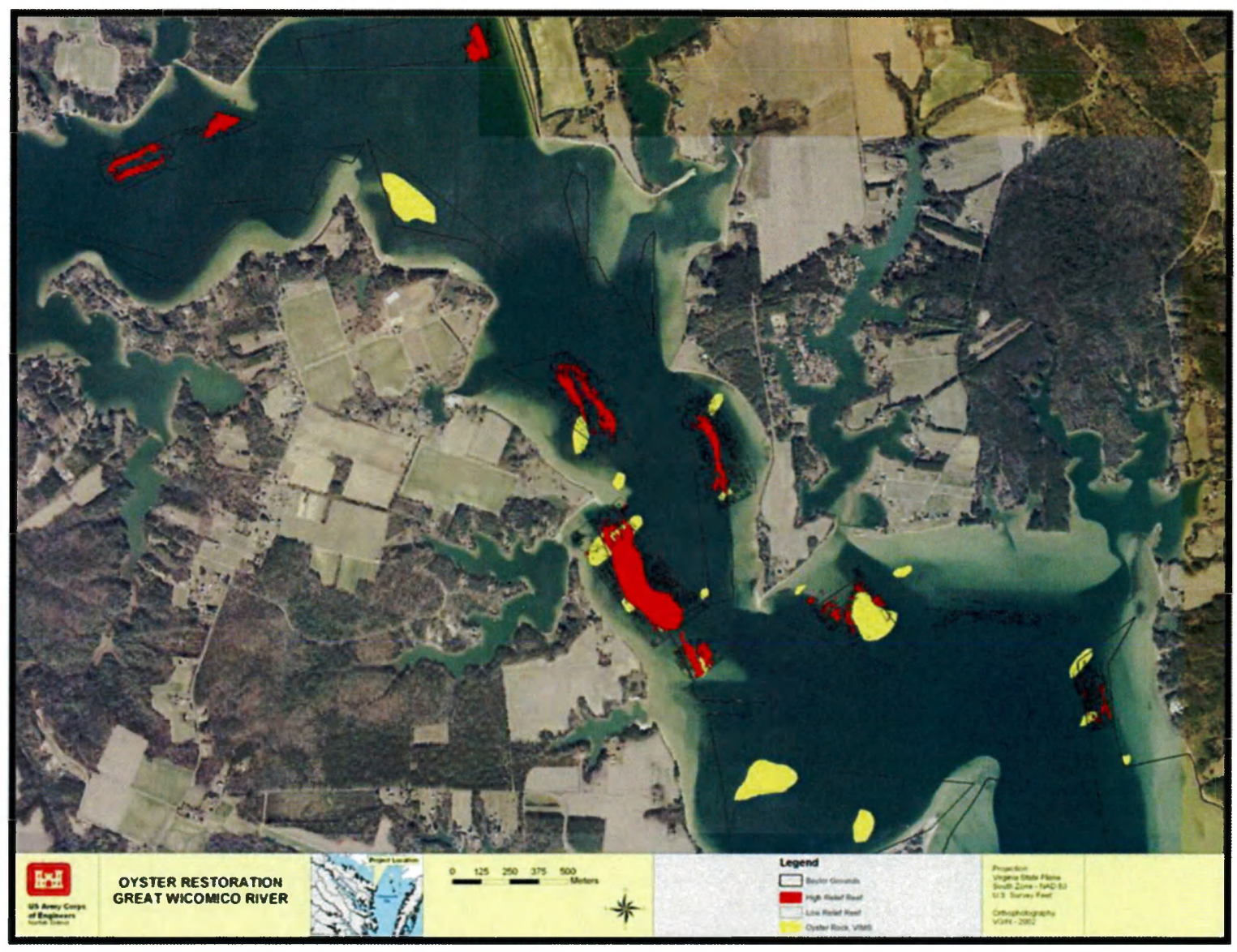

Figure 1: Map of the reef sites in the Great Wicomico River, Chesapeake Bay. HRR is indicated in red, LRR by stippling, and UNB by the remaining area in each of the Baylor Ground polygons. 


\section{Pre-Restoration survey}

A pre-restoration survey with patent tong samplers was conducted throughout the unrestored, potential oyster reef habitat in the Great Wicomico River, a small sub-estuary on the western shore of the Chesapeake Bay just South of the Potomac River (Fig. 1) in Northumberland County, Virginia at approximately N 37.8043 and W -76.268. The survey consisted of 63 samples across the nine reef complexes (Figs. 1 and 2), and none of the samples had more than 2 oysters per $\mathrm{m}^{2}$ (Fig. 2). This pre-restoration survey served as the "Before-Control" element of a "Before-After Control-Impact" experimental design.

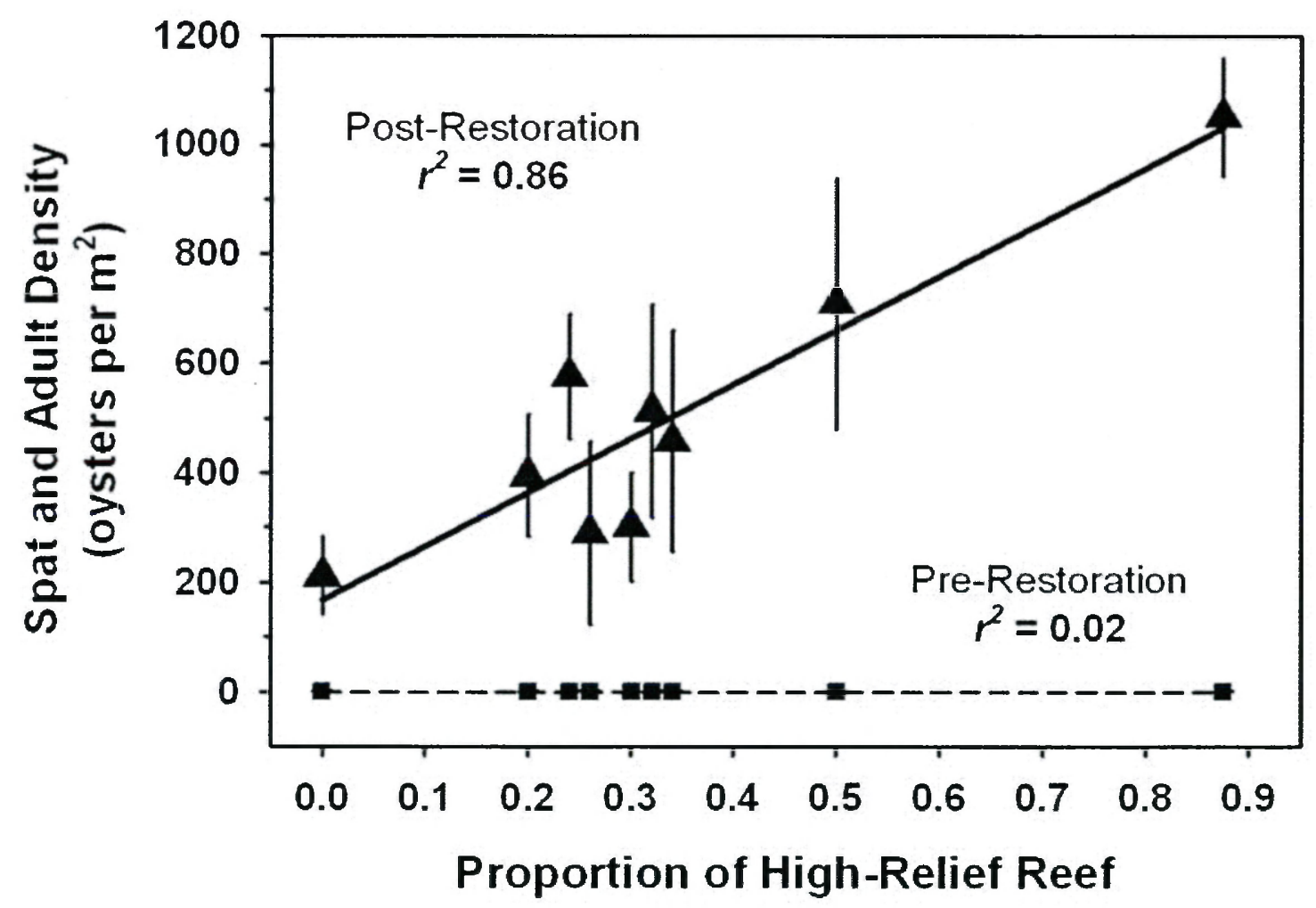

Figure 2: Combined spat and adult oyster density as a function of the proportion of sampled HRR plots on each of the nine reefs [Least-squares regression; Spat and adult density $=165.5+992.8 \mathrm{x}$ (Proportion HRR), $\left.r^{2}=0.86, n=9\right]$. 


\section{Construction}

The U. S. Army Corps of Engineers (USACE) attempted to construct approximately 42.5 ha of oyster reef habitat in fall of 2004 by placing dredged and washed oyster shells removed from former productive reef footprints in the lower James River. These areas were not the most suitable habitat available in the river, but were areas classified as "shell-sand" and "shell-mud" rather than high-quality hard bottom known as "oyster rock" in a 1981 survey (Fig. 1). Areas of high-quality bottom were set aside for the public common-access oyster fishery by the Virginia Marine Resources Commission. This practice is common when combining fishery and ecological restoration, forcing sanctuaries for ecological restoration to be placed on marginal bottom (e.g. soft muds), which hinders reef performance and persistence, thereby fostering the belief held by some that native oyster restoration cannot succeed. The USACE responded to the problems of having to build reefs on sub-optimal bottom and the suspected ephemeral nature of low-relief reefs by constructing high-relief reefs over a large portion of the project area to increase the chances of project success. This proved to be a wise decision.

\section{Post-Restoration survey}

The patent tong survey was conducted throughout the restored oyster reef areas (Fig. 1). Underwater video was used to document the reef condition and appearance at various locations during the patent tong survey. The filming occurred immediately adjacent to the patent tong sample sites. The patent tong survey, along with associated underwater video, indicated that the USACE reefs encompassed 38.7 ha initially and as of fall 2007, 35.2 ha remained, an approximately $9 \%$ rate of loss over the four year period 
since the reefs were constructed. Due to the vagaries of the shell placement technique, which consisted of blowing the dredged shells, with a water cannon, over the area to be restored from a barge into the water, approximately $10 \%$ of the area the USACE had attempted to build reefs on never received any shells. Due to subsidence, a significant portion of the HRR strata had essentially degraded to LRR. This resulted in a $33.9 \%$ loss of HRR acreage to the LRR strata, which gained in size as a result. Much of this loss occurred toward the main channel of the Great Wicomico River on reefs in waters deeper than $6 \mathrm{~m}$. The reef areas lost were typically on areas of softer sediments and had little shell; in some cases only approximately $2-4 \mathrm{~cm}$ of shells remained. The shells became completely covered with sediment and were no longer available as settlement substrate for oyster larvae. Any spat or adults observed on these shells had died due to anoxia. The restored reefs were all constructed above Sandy Point, in a stretch of river known to have a relatively small tidal exchange. All restored reefs were intended to be fully within various Baylor (public) oyster grounds, but a substantial percentage of most of the nine reefs extended outside of the Baylor grounds. Though bottom categorized as Baylor grounds did not necessarily include all natural oyster reefs, it is a reasonable guide for the location of subtidal oyster reefs in Virginia waters of the Chesapeake Bay. The Baylor grounds encompassing the project cover a total of 194.2 ha and contain many habitat types, including former reef footprints consisting of hard shell, sand-shell and mud-shell mix, sand, clay, and mud. Due to the inherent difficulties in deploying shells off a barge using a water cannon to create shell beds of uniform thickness, some areas intended to receive shells did not, and some areas near but outside the Baylor grounds did. This heterogeneous placement of shell is typical of such construction, and the area of bottom 
covered is not strongly correlated with the volume of shell used. The direct result was the deployment of reefs of various heights and configurations, as well as areas devoid of shell, within the Baylor areas targeted for restoration. Recent observations (2009) have shown that some of the high quality LRR on the edge of the remaining (after the $33.9 \%$ loss due to subsidence) HRR has achieved a dense population that has accreted enough additional shell material to now be considered HRR.

\section{Estimate of 1994 oyster population in Great Wicomico River (GWR)}

To generate the population increase due to the restoration effort in the GWR over a historical time frame, we used estimates of abundance derived from the 1994 dredge survey by the Virginia Institute of Marine Science and Virginia Marine Resources Commission (the status of Virginia's public oyster resource 2004 report). From the dredge survey, abundance of spat, small adults and large adults were combined into a total average of 110 per bushel (16 spat +87 small adult +7 large adult per bushel). Each dredge tow collected 1.5 bushels and sampled $55 \mathrm{~m}^{2}$, with an average efficiency of $18 \%$ and range in efficiency from 2-26\%. The area of bottom inhabited by the oyster population was estimated as 19.425 ha, which represents areas of high-quality oyster habitat (= "oyster rock") as defined in previous surveys (Fig. 1). The resultant average estimate $=1.5 \times 110$ oysters $/ 55 \mathrm{~m}^{2} \times 100 / 18 \times 194250 \mathrm{~m}^{2}=3.244$ million oysters. If the dredge efficiency was $2 \%$, estimated abundance $=9.011$ million, and if $26 \%$ it would be 0.693 million. 


\section{RESULTS and DISCUSSION}

In 2007 , the metapopulation on the nine reefs consists of an estimated 184.5 million oysters, comprising 119.2 million adults of two age classes (2005 and 2006) and 65.3 million juveniles of the 2007 age class (Figs. 3 and 4), indicating protracted survival of settled individuals to adulthood and recruitment of larvae to the reefs. This represents a 57-fold augmentation of the resident Great Wicomico River population, which greatly exceeds the previously unachieved restoration goal (10-fold increase of 1994 baseline by 2010) of the Chesapeake Bay Program. Moreover, the reef complex continued to develop and still persists five years post construction (March 2009), as evident in 2009 video and patent tong surveys (Fig. 5a-f).

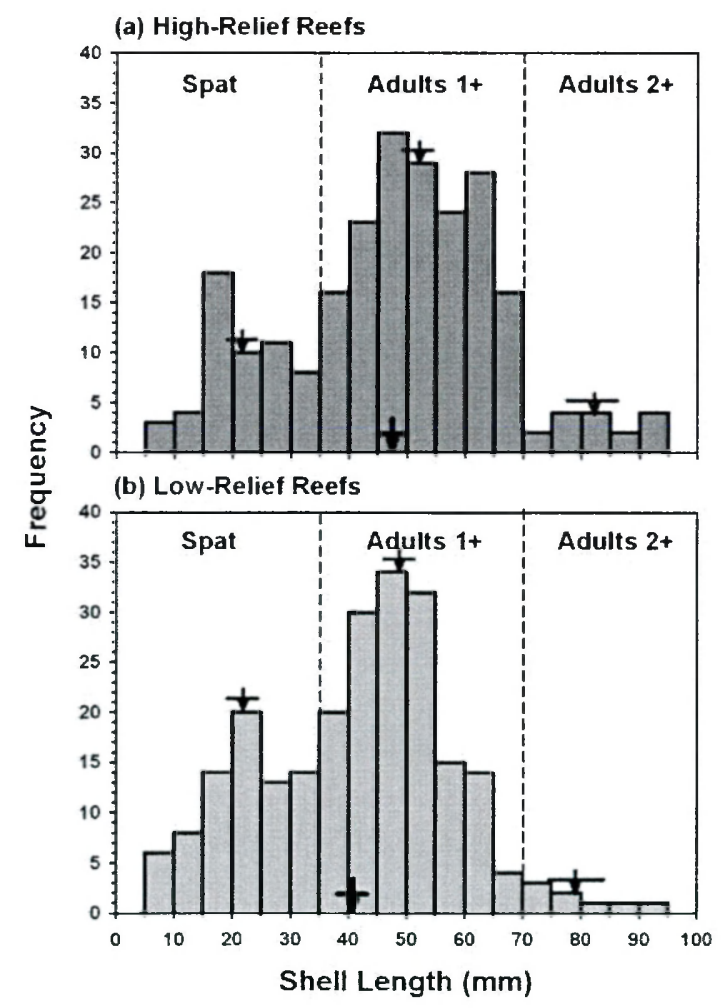

Figure 3: Size-frequency distributions of Crassostrea virginica on (a) HRR and (b) LRR treatments. Upper Crosses indicate average size of year $0,1+$ and $2+$ year old oysters, the lower cross indicates the average size of oysters on HRR and LRR, respectively. 

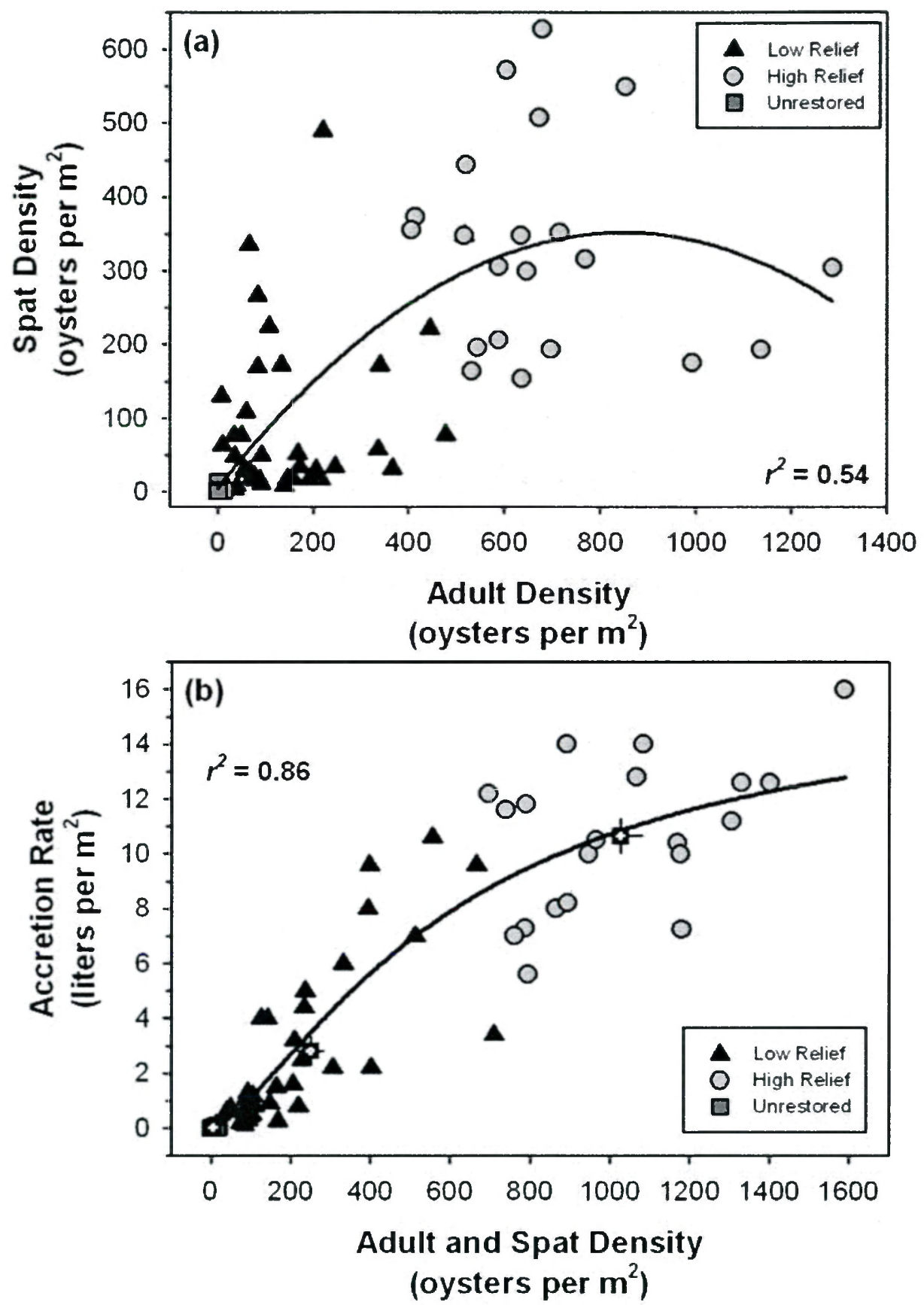

Figure 4: (a) Spat density as a function of adult density and (b) Accretion rate as a function of adult and spat density on each of the 85 one-square-meter plots sampled across the nine reefs. [Non-linear least-squares regression; (a) Spat density $=4.672+0.818 \times$ (Adult Density) $-0.001 \mathrm{x}$ (Adult Density) $)^{2}, r^{2}=0.54, n=85$; (b) Accretion rate $=-0.302+16.860 \times\left(1-\mathrm{e}^{-0.001 x \text { Adult and Spat }}\right.$ Density), $r^{2}=0.86, n=85$ ]. In (b) the squares and associated crosses represent the means and SEs for each of the three treatments. 


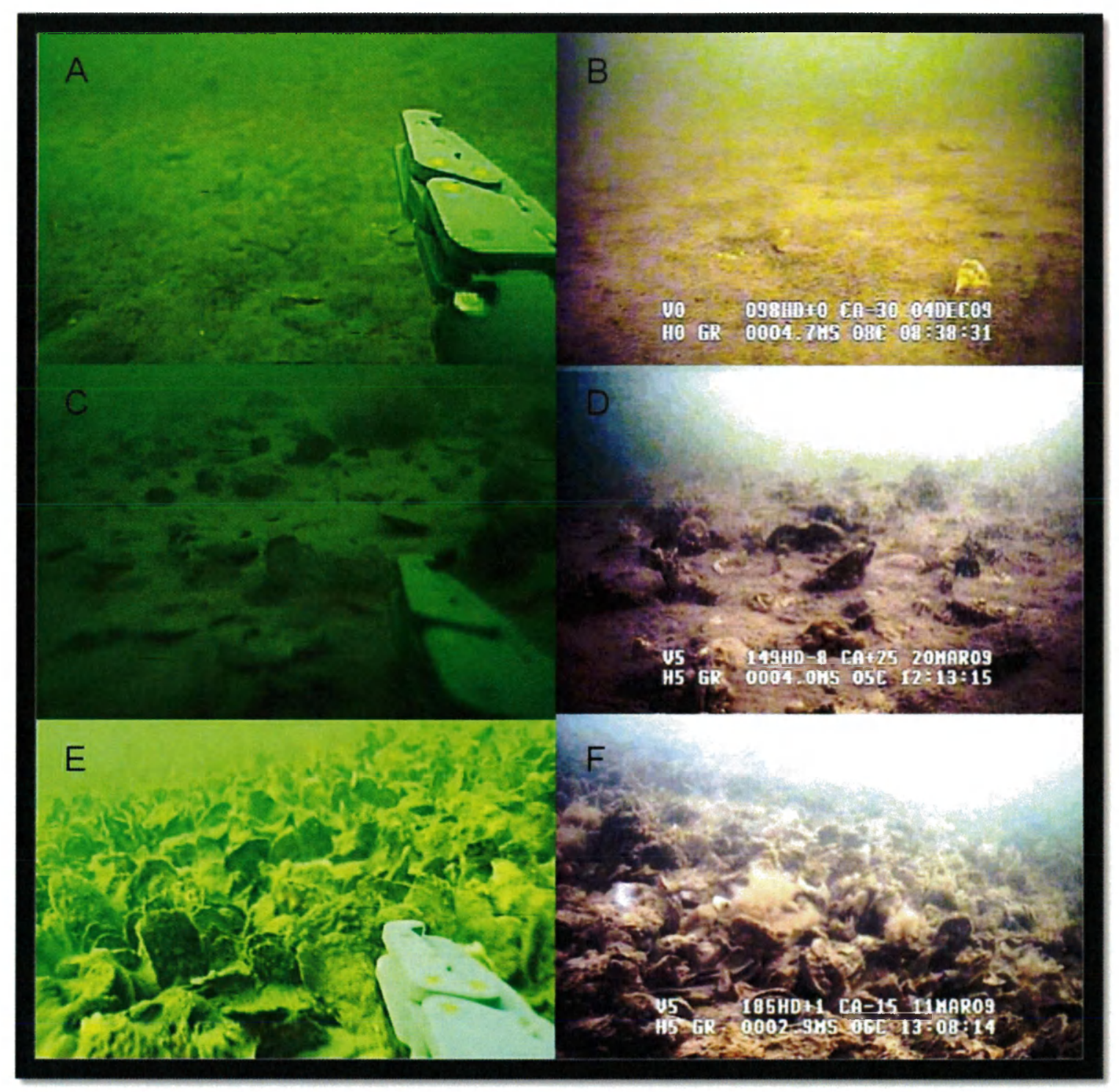

Figure 5: Time series of (A, B) UNB, (C, D) LRR and (E, F) HRR between 2007 and 2009.

The 185-million-strong population in the Great Wicomico River dwarfs all individual populations throughout Maryland's 111,600 ha of public oyster grounds in upper Chesapeake Bay (Tarnowski 2007), and is nearly as large as the estimated 200 million oysters in all of Maryland waters. Comparisons to native oyster populations in other parts of the world similarly demonstrate the unrivaled magnitude of the restoration. 
The largest documented populations of native oyster species comprise 24 million flat oyster Ostrea anagasi in Tasmania (Mitchell et al. 2000) and 100 million European flat oyster Ostrea edulis in the Mediterranean (Airoldi and Beck 2007). For all other native oyster species, there is little data but their populations are much smaller than the Great Wicomico River population (Rothschild et al. 1994, Kirby 2004, Ruesink et al. 2005, Lotze et al. 2006).

The major influence upon oyster reef success was reef height, which drove abundance and density across the reef complexes (Fig. 6). Despite their much smaller area (12.1 ha), HRR segments harbored $67 \%$ or 123.8 million oysters (Fig. 6a), whereas the 23.2 ha of LRR contained $32 \%$ or 58.1 million (Fig. 6a), and 43.5 ha of UNB held only $1 \%$ or 2.6 million (Fig. 6a). Irrespective of reef type, adults were twice as abundant as young juveniles (Fig. 6). Mean oyster density per $\mathrm{m}^{2}$ was four-fold higher on HRR $(1026.7 \pm 51.5 \mathrm{SE})$ than on LRR $(250.4 \pm 32.3 \mathrm{SE}) ; \mathrm{UNB}$ only had $6.0( \pm 1.5 \mathrm{SE})$ oysters $/ \mathrm{m}^{2}$ (Fig. 6b). The HRR density stands in sharp contrast to the typical average densities on Chesapeake Bay sanctuary reefs, which have $100-152$ oysters $/ \mathrm{m}^{2}$. On harvested reefs in Chesapeake Bay, oysters exist at much lower densities (2-11 oysters $/ \mathrm{m}^{2}$ ); some harvested reefs harbor higher densities up to 350 oysters $/ \mathrm{m}^{2}$, but these are unusual.

The key feature mediating the abundant restored population was the vertical relief of the restored reefs, specifically the height above the river bottom (HRR: $25-45 \mathrm{~cm}$ and LRR: 8-12 cm, prior to subsidence of $2-6 \mathrm{~cm}$ due to settling) of the oyster shell used to build the reefs. As the proportion of HRR increased on any particular reef, oyster density rose sharply from 200 oysters $/ \mathrm{m}^{2}$ when a reef was $10 \%$ HRR to over 1000 oysters $/ \mathrm{m}^{2}$ 
when a reef was $90 \%$ HRR (Fig. $2, r^{2}=0.86$ ). For every $10 \%$ increase in the proportion of HRR, oyster density rose by 100 oysters $/ \mathrm{m}^{2}$ (Fig. 2). Similarly, oyster size (shell height) on HRR (47.3 mm $\pm 1.2 \mathrm{SE}$; Fig. 3A) was $15 \%$ larger than that on LRR $(41.0 \mathrm{~mm}$ \pm 1.1 SE; Fig. 3B). The mechanism mediating the superiority of HRR over LRR was most likely due to the optimal flow rates and corresponding healthier physiological condition of oysters on HRR, which maximize growth and survival and minimize disease influence and sedimentation (Lenihan and Peterson 1998, Lenihan 1999).

The sharply magnified oyster densities on HRR had two profound benefits for the long-term sustainability of the restored population (Fig. 4a) and the persistence of the associated reef matrix (Fig. 4b). First, there was a positive feedback between adult density and subsequent juvenile recruitment such that spat density was a positive parabolic function of adult density, with a peak at an adult density of 850 oysters $/ \mathrm{m}^{2}$, after which juvenile recruitment declined (Fig. 4a). Variance in juvenile recruitment also differed by reef type (Fig. 4a), and was distinctly lower on HRR (coefficient of variation $=43 \%)$ than on LRR (129\%). Thus, recruitment was not only much greater on HRR, but it was also more consistent than the variable and lower recruitment on LRR (Fig. 4a).

Oyster reefs require an accumulation of accreting shell (i.e. the conglomeration of shell from living and dead oysters) that develops vertically with a complex architecture, and which serves as the base for the extant population, spat settlement and reef persistence. Accretion rate of shell material on restored reefs was a sigmoid function of total oyster density and differed substantially by reef type: $6-16 \mathrm{~L} / \mathrm{m}^{2}$ on $\mathrm{HRR}$ and $<4$ $\mathrm{L} / \mathrm{m}^{2}$ on LRR (Fig. 4b). Historically, accretion rates exceeding $5 \mathrm{~L} / \mathrm{m}^{2}$ characterized successful native oyster reefs (DeAlteris 1988). The vertical growth and cohesiveness of 
HRR indicate that they are coalescing into the historic, natural oyster reef architecture typical of pre-exploitation reefs (DeAlteris 1998), as evident in the photographs and video clips of 2007 and 2009 (Fig. 6). These results suggest that oyster reefs exist in two alternative states (Scheffer and Carpenter 2003), one a heavily sedimented degraded state and the other a vertically accreting, elevated reef configuration comprised of abundant oysters, which provides a positive feedback to reef integrity.

It has been suggested recently that native oyster restoration cannot succeed because restored reefs do not accrete reef material at sufficient rates to compensate for losses due to shell degradation and sedimentation (Powell et al. 2006, Mann and Powell 2007). This conclusion is based on data from restored reefs characterized by poor habitat quality (e.g. low reef height), low recruitment, low standing stock, and ongoing exploitation, which destroys the reef architecture and removes large adults from the population (Lenihan and Peterson 2004). Such reefs are comparable to the poorly performing LRR in the Great Wicomico River. In contrast, HRR are accreting shell at rates significantly faster than $5.0 \mathrm{~L} \mathrm{~m}^{-2} \mathrm{yr}^{-1}$, indicating that $\mathrm{HRR}$ has developed into a robust, permanent reef structure, whereas much of the LRR is not likely to persist more than a few years. The HRR exhibit both vertical and cohesive growth, in contrast to the pattern of reef degradation typically observed on previous native oyster restoration projects (Smith et al. 2005). Our recent patent tong samples and UW ROV observations in March 2009 indicate that recruitment of the 2008 year class was very successful and that the reefs are continuing to develop and grow, attesting to the expansion and persistence of the reef matrix. The HRR system has persisted and, more importantly, thrived for nearly five years, well past the typical longevity of failed oyster reefs (Smith 
et al. 2005). The HRR are gaining shell material and establishing oyster densities at rates previously unrecorded on native oyster restoration projects.
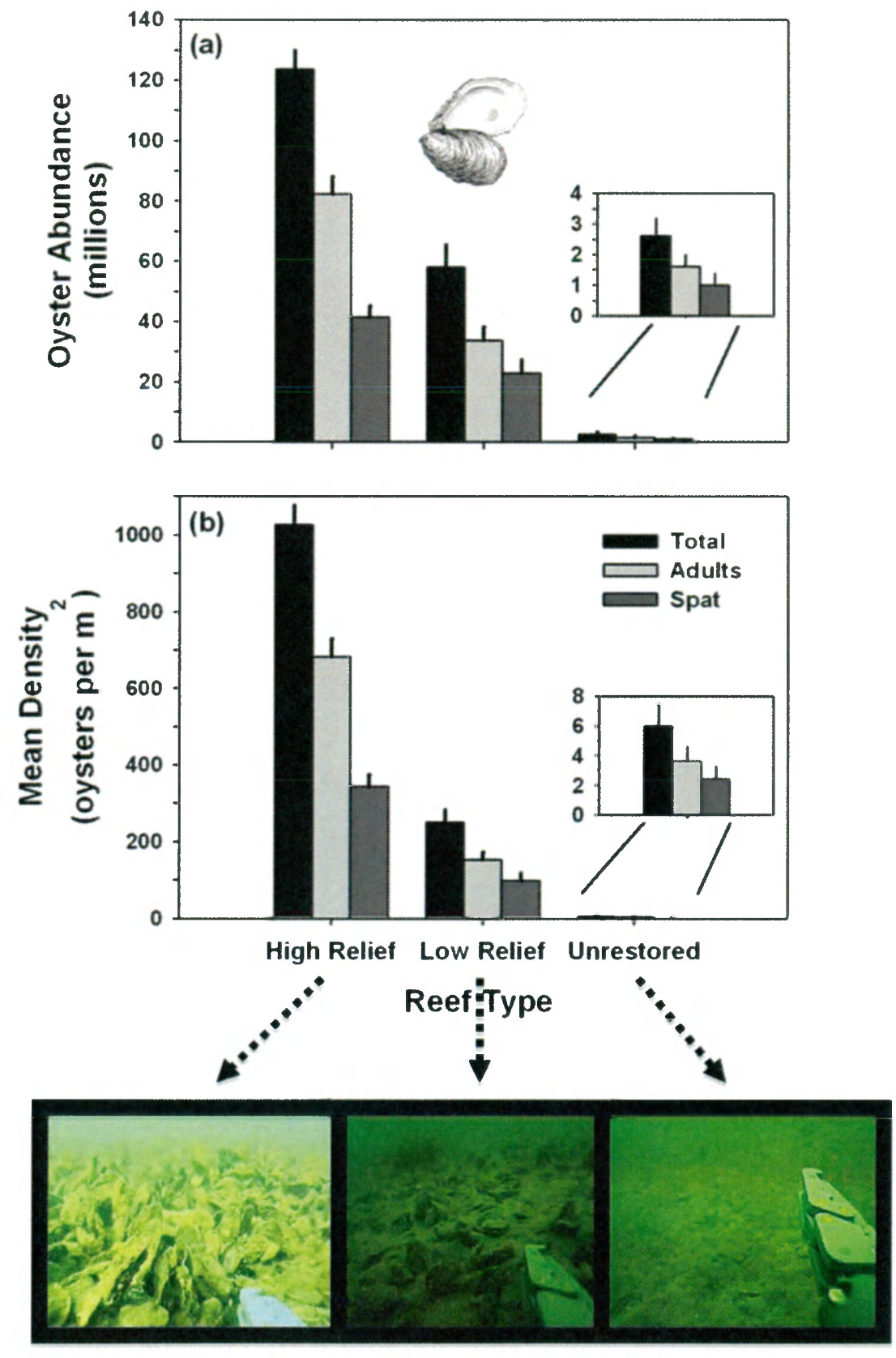

Figure 6: (a) Oyster abundance and (b) Density on each of the reef types across the nine-reef system. Values for UNB are magnified to demonstrate the similar pattern in adult and spat abundance as on the HRR and LRR patches. Abundance estimates for the system of nine reefs consisted of a total of 184.5 million oysters (95\% CI: 165.0-204.0 million), 119.2 million adults (95\% CI: 104.5-133.9 million) of the 2005 and 2006 year classes, and 65.3 million spat (95\% CI: 59.7-77.2 million) of the newly recruited 2007 year class (Fig. 1). 
The native oyster metapopulation on the restored reef system in the Great Wicomico River greatly exceeds recently proposed criteria for sustainability (Powers et al. 2009): (1) it is comprised of multiple year classes at high abundance, which buffers year-to-year variation in spat settlement; (2) it is composed of young and old adults that have survived disease challenge; (3) the reefs are accreting (i.e. growing) at a rate that will provide settlement habitat for future generations; and (4) it receives sufficient spat settlement and recruitment to sustain the population over the long term.

The recent recovery of a native Crassostrea virginica metapopulation in the Great Wicomico River of Chesapeake Bay, as well as limited successes in other North American estuaries (Lipcius and Burke 2005, Nestlerode et al. 2007, Taylor and Bushek 2008, Powers et al. 2009), highlight the critical importance of two common features of successful reefs-protection from fishing and high vertical relief (Lenihan and Peterson 1998, 2004, Lenihan 1999, Lenihan et al. 1999). Past oyster restoration efforts operated under the mistaken premise that fishery and ecological restoration could be accomplished simultaneously (Mann et al. 1991, US Army Corps 2009). This approach failed to stem the decline in oyster stocks, and led to the widespread use of more efficient fishery methods such as power dredging, the most destructive technique of harvesting oysters (Lenihan and Peterson 2004, Smith et al. 2005). This strategy promoted partial fishery recovery via put-and-take fisheries at the expense of ecological restoration, and consequently perpetuated the precipitous decline of oyster populations in Chesapeake Bay as well as along the Atlantic and Gulf of Mexico coasts of North America (Rothschild et al. 1994, Jackson et al. 2001, Kirby 2004, Lotze et al. 2006). 
The Great Wicomico River restoration project deviated significantly from prior restoration attempts in the Chesapeake Bay by building oyster reefs of high vertical relief at a broad spatial scale in large sanctuaries protected from fishery exploitation, and in locations characterized by high recruitment (Schulte 2003, Tarnowski 2007). Typical restored sanctuaries prior to this project amounted to $1 \%$ or less of an estuary's original oyster reef extent. The Great Wicomico River reef network encompasses approximately $40 \%$ of the original oyster reef extent (Berman et al. 2002) within a hydrodynamically restricted system (Schulte 2003). This metapopulation connectivity promotes persistence of individual populations in the network and larval subsidies from protected source reefs to fished reefs (Lipcius et al. 2008) with the attendant economic benefits (Grabowski et al. 2007). Designation of the reefs as sanctuaries protects the reefs both from exploitation of the spawning stock and physical destruction of the critically important vertical structure. Significant vertical relief and reef persistence were accomplished by building a substantial portion of the reef system as high as $45 \mathrm{~cm}$ (HRR) in contrast to the $8-12 \mathrm{~cm}$ LRR, which typically does not promote reef persistence more than 3-5 years (Smith et al. 2005). Low-relief reefs have been the construction method of choice by fishery management agencies in the Chesapeake and several other estuaries. The ephemeral nature of low-relief reefs has proven to be one of the main impediments to the recovery of native oyster habitat wherever they are used.

The vertical growth and cohesiveness of HRR indicate that they are coalescing into the historic, natural architecture typical of pre-exploitation oyster reefs (Winslow 1881), as evident in the photographs (Fig. 6). Winslow (1881), during his historic survey of oyster reefs, documented perhaps the last unexploited reefs in Chesapeake Bay. These 
reefs consisted of "long, narrow oysters...no single oysters of any [age] class, but all grew in clusters of 3 to 15 . The shells were clean and white, free from mud and sand. The mature oysters were covered and the interstices between them filled with younger oysters." Moreover, he noted that it was very difficult to sample these reefs due to their cohesive nature, which we also experienced when attempting to sample HRR during our 2009 survey.

Although disease will kill some oysters in the Great Wicomico River, the recent development of disease tolerance in oysters on sanctuary reefs of lower Chesapeake Bay (Encomio et al.2005) bodes well for the long-term persistence of this metapopulation and its attendant ecosystem benefits (Grabowski et al. 2007). Similar approaches with other natural (Taylor and Bushek 2008) and artificial reefs (Schulte et al. 2009) could lead to recovery of the native oyster throughout North America, as well as other ecosystems worldwide where native oysters have been functionally extirpated (Jackson et al. 2001, Lotze et al. 2006). 


\section{Closing Thoughts}

Working towards restoration of native oyster to lower Chesapeake Bay with the primary focus on ecology and population recovery, not commercial fishery augmentation, has been a very difficult endeavor and one that I may not have taken up had I known how politically charged it was. Upton Sinclair put it nicely when he said: "It is difficult to get a man to understand something, when his salary depends on his not understanding it." 


\section{Appendices}

Appendix 1.1: Data Table of the winter 2007-8 survey in the Great Wicomico River, Virginia on the US Army Corps built sanctuary reefs 


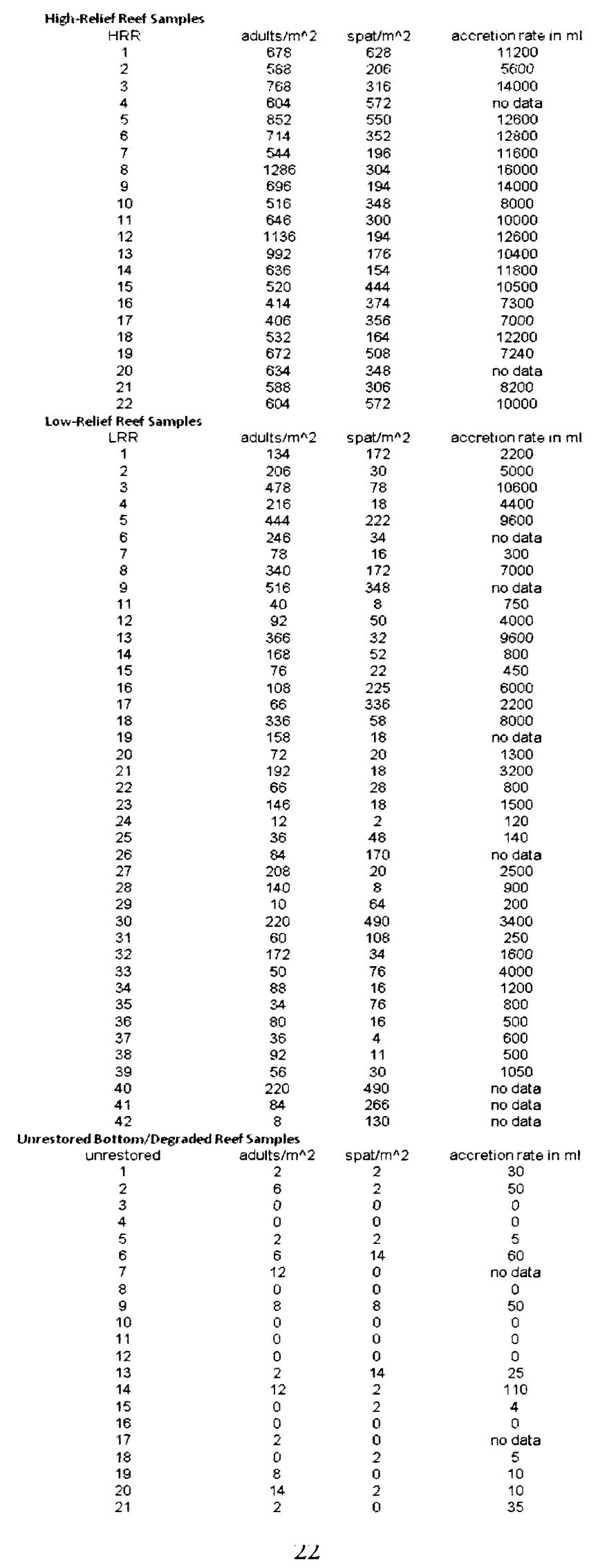




\section{Literature Cited}

Airoldi L, Beck MW (2007) Loss, status and trends for coastal marine habitats of Europe. Oceanogr Mar Biol Ann Rev 45:345-405

Berman MR, Killeen S, Mann R, Wesson JA (2002) Virginia oyster reef restoration map atlas. Virginia Institute of Marine Science, Gloucester Point, Virginia. $44 \mathrm{pp}$

Chai A-L, Homer M, Tsai C-F, Goulletquer P (1992) Evaluation of oyster sampling efficiency of patent tongs and an oyster dredge. N Am J Fish Manage 12:825-832

DeAlteris JT (1988) The geomorphic development of Wreck Shoal, a subtidal oyster reef of the James River, Virginia. Estuaries 11:240-249

Encomio VG, Stickler SM, Allen, Jr. SK, Chu F-L (2005) Performance of "natural Dermo-resistant" oyster stocks - survival, disease, growth, condition and energy reserves. J Shellfish Res 24(1):143-155

Grabowski JH, Peterson CH (2007) Restoring oyster reefs to recover ecosystem services p. 281-298. In:Ecosystem Engineers, (eds) K. Cuddington, JE Byers, WG Wilson and A Hastings. Elsevier, NY

Haven DS, Whitcomb JP, Kendall PC (1981) The present and potential productivity of the Baylor Grounds in Virginia. Special Report in Applied Marine Science and 
Ocean Engineering No. 243. Virginia Institute of Marine Science, Gloucester Point, VA 23062

Haven DS, Hargis WJ, Kendall PC (1978) The oyster industry of Virginia: its status, problems and promise. VIMS Special Papers in Marine Science, Virginia Institute of Marine Science, Gloucester Point, VA 23062

Jackson JBC, Kirby MX, Berger WH, Bjorndal KA, Botsford LW, Bourque BJ, Bradbury RH, Cooke R, Erlandson J, Estes JA, Hughes TP, Kidwell S, Lange CB, Lenihan HS, Pandolfi JM, Peterson CH, Steneck RS, Tegner MJ, Warner RR (2001). Historical overfishing and the recent collapse of coastal ecosystems. Science $293: 629-637$

Kirby MX (2004) Fishing down the coast: historical expansion and collapse of oyster fisheries along continental margins. Proc Nat Acad Sci 101(35):13096-13099 Lenihan HS, Peterson CH (1998) How habitat degradation through fishery disturbance enhances impacts of hypoxia on oyster reefs. Ecol Appl 11:128-40

Lenihan HS (1999) Physical-biological coupling on oyster reefs: how habitat form influences individual performance. Ecol Monogr 69:251-275

Lenihan HS, Micheli F (1999) The influence of multiple environmental stressors on susceptibility to parasites: An experimental determination with oysters. Limnol Oceanog 44(3, part 2):910-924

Lenihan HS, Peterson CH (2004) Conserving oyster habitat by switching from dredging and tonging to diver hand-harvesting. Fish Bull 102:298-305

Lipcius RN, Burke RP (2006) Abundance, biomass and size structure of eastern oyster and hooked mussel on a modular artificial reef in the Rappahannock River, 
Chesapeake Bay. Special Report in Applied Marine Science and Ocean Engineering No. 390, Virginia Institute of Marine Science, The College of William and Mary, Gloucester Point, VA 23062

Lipcius RN, Eggleston DB, Schreiber SJ, Seitz RD, Shen J, Sisson M, Stockhausen, WT, Wang HV (2008) Importance of metapopulation connectivity to restocking and restoration of marine species. Rev Fish Sci 16(1-3):101-110

Lotze HK, Lenihan HS, Bourque BJ, Bradbury, RH, Cooke RG, Kay MC, Kidwell SM, Kirby MX, Peterson CH, Jackson JBC (2006) Depletion, degradation, and recovery potential of estuaries and coastal seas. Science 312:1806-1809

Mann R, Burreson EM, Baker PK (1991) The decline of the Virginia oyster fishery in Chesapeake Bay: considerations for introduction of a non-endemic species, Crassostrea gigas (Thunberg, 1793). J Shellfish Res 10(2):379-388

Mann R, Powell EN (2007) Why oyster restoration goals in the Chesapeake Bay are not and probably cannot be achieved. J Shellfish Res 26(4):1-13

Mitchell M, Crawford CM, Rushton MJ (2000) Flat oyster Ostrea angasi growth and Survival rates at Georges Bay, Tasmania (Australia). Aquaculture 191:309-321

Nestlerode JA, Luckenbach MW, O'Beirn (2007) Settlement and survival of the oyster Crassostrea virginica on created oyster reef habitats in Chesapeake Bay. Rest Ecol 15(2):273-282

Powell EN, Kraeuter JN, Ashton-Alcox KA (2006) How long does oyster shell last on an oyster reef? Est Coast Shelf Sci 69:531-542 
Powers SP, Peterson CH, Grabowski JH, Lenihan HS (2009) Success of constructed oyster reefs in no-harvest sanctuaries: implications for restoration. Mar Ecol Prog Ser 389:159-170

Rothschild BJ, Ault JS, Goulletquer P, Heral M (1994) Decline of the Chesapeake Bay oyster population: a century of habitat destruction and overfishing. Mar Ecol Prog Ser 111:29-39

Ruesink JL, Lenihan HS, Trimble AC, Heiman KW, Micheli F, Byers JE, Kay MC (2005) Biotic resistance and facilitation of a non-native oyster on rocky shores. Ann Rev Ecol Evol Syst 36:643-689

Scheffer M, Carpenter SR (2003) Catastrophic regime shifts in ecosystems: linking theory to observation. Trends Ecol Evol 18(12):648-656

Schulte DM (2003) Final Decision Document Amendment, Section 704B as Amended, Chesapeake Bay Oyster Recovery Phase III, Great Wicomico River, Virginia. Norfolk District - United States Army Corps of Engineers. Norfolk, Virginia $23510-1096$

Schulte DM, Ray G, Shafer DJ (2009) Use of alternative materials for oyster reef construction. Ecosystem management and restoration research program (EMRRP) Technical Note TN-EMRRP-ER-12

Smith GF, Bruce DG, Roach EB, Hansen A, Newell RIE, McManus AM (2005) Assessment of recent habitat conditions of eastern oyster Crassostrea virginica bars in mesohaline Chesapeake Bay. N Am J Fish Manage 25:1569-1590 Tarnowski MT (2007) Maryland oyster population status report. Maryland Department of Natural Resources, Annapolis MD. 
Taylor J, Bushek D (2008) Intertidal oyster reefs can persist and function in a temperate North American Atlantic estuary. Mar Ecol Prog Ser 361:301-306

United States Army Corps of Engineers (2009) Final programmatic environmental impact statement for oyster restoration in Chesapeake Bay including the use of a native and/or nonnative oyster. Norfolk, VA 23510

Winslow F (1881) Deterioration of American oyster beds. Pop Sci Monthly $20: 145-156$

http://web.vims.edu/mollusc/NORM/NORMdatahub/NORMGGGWsplants.htm (Virginia Institute of Marine Science, The College of William and Mary, Gloucester Point, VA). 


\section{VITA}

\section{DAVID MARTIN SCHULTE}

David was born in 1968 in Dayton, Ohio. He was raised in Pennsylvania and graduated from high school there in 1986, then from Millersville University in 1991 with a BS degree in Biology (Marine/Environmental options). He finished what has become a MS program at VIMS in the fall of 2012. 